\title{
Uncanny History: Temporal Topology in the Post-Ottoman World
}

\author{
Charles Stewart (University College London)
}

FORTHCOMING in Social Analysis, vol. 61, no. 1, 2017

\begin{abstract}
Post-Ottoman temporal topologies-cases where the past, present, and future may be bent around one another rather than ordered linearly-may produce uncanny histories. The uncanny is activated, as Freud noted, when something secret comes to light, but also when the expectations of a given genre are exceeded. In these cases, the genre of historicism has been violated. Rather than contending that the post-Ottoman world is entirely different from Western Europe, the examples here alert one to the presence of uncanny histories in many other places since historicism has nowhere managed to eradicate its alternatives. Unsettled pasts of violence and displacement and presents beset by ongoing tensions (political, economic, religious/ethnic) do contribute, however, to a particular vitality and saliency of uncanny histories in the post-Ottoman sphere.
\end{abstract}

Keywords: Alevis, Freud, genres of history, Greek Civil War, myth, topological history, the uncanny

In this article I explore the poetics of history in the post-Ottoman world by examining how people configure the connections between events past, present, and future. Mental maps of time exist everywhere (Zerubavel 2003), and they do not come in discrete cultural packages as Eliade's (1971) typology of archaic (static, circular), Christian (teleological), and modern (linear, random) might lead one to think. They are not singular within any given society, but multiple and often in competition. They may alternate as Leach (1961) observed in his classic essay on the symbolic representation of Western time, where anxiety about linearity is moderated by images of cyclicity on a regular basis; or one type of time may suppress another as in Bloch's (1977) argument that rituals reproduce the ideological status quo of the past, thereby obscuring novel practical ideas arrived at through everyday activity. Even anthropology itself is not immune to conflicts over time models as evidenced by Robbins's (2007) claim that a fascination with cultural continuity has prevented the study of discontinuity. 
Usually, one particular conception of historical time predominates in a given society as the unmarked or taken-for-granted assumption. For contemporary Western societies, this concept is linearity, which governs everyday rationality, science, and historiography (Burke 2001), and it is conventionally recognized by the term 'historicism' (e.g., Chakrabarty 2000: 7). The historicist timeline emerged visually in the eighteenth century in the diagrams of Priestley, who plotted the lives of great thinkers as lines running horizontally across the page (Rosenberg and Grafton 2010: 18f.). The ascendance of linearity cast alternative ideas into higher relief (as anomalies), an example being the time charts printed in Laurence Sterne's Tristram Shandy (published in nine volumes between 1759 and 1767). In the sixth volume, Sterne presented diagrams of the story line in each of his preceding five books (fig. 1). The loops and squiggles indicate digressive narrative leaps going backward and forward in time in what might be the earliest graphic representation of temporal topology.1 These diagrams arose as a comic foil to linearity, yet they captured the non-linear human engagement with time, which continued in the shadow of linearity.2 This example opens the theme I intend to pursue below, namely, the affective, political, and existential attributes of topological time and its juxtaposition to linear time (Rosenberg and Grafton 2010: 244).

The concept of 'the uncanny' reflects a further stage in the naturalization of linear temporal thought and also the effects of parallel Enlightenment tenets, such as objectivity (the value of tangible evidence), the scientific method, and the ideal of dispassionate inquiry. According to the Oxford English Dictionary, the term 'uncanny' did not become common in its current meaning of "partaking of a 
supernatural character; mysterious, weird, uncomfortably strange or unfamiliar" until 1850. It could be understood as the residue formed by the expansion of science at the expense of religion, a crepuscular category where eerie and unsettling phenomena gradually accumulated (García Marín 2015; Royle 2003: 22).

The transformation of Enlightenment reason into intuitive ontology has not, however, been unidirectional or complete. In Latour's (1993) formulation, we have never been modern but rather continue to fluctuate between the expectations of post-Enlightenment reason and sensitivity to experiences where these expectations are violated. 'We' are ontologically 'multimodal' (Harris and Robb 2012: 676) with respect to history, as are post-Ottoman societies and every other society that has internally produced, or come into contact with, competing systems of thought. The "Uncanny History" of my title refers to cases of post-Ottoman topological historicizing where the past is not in its expected place. This may evoke an affective response not through intellectual surprise alone, but, as Freud contended, on account of the shocking immediacy of the encounter with powerful ideas and emotions from the past. 3

The post-Ottoman world has no monopoly on uncanny histories, yet the violent recent past of the region has contributed to making local histories a "perpetual calendar of human anxiety" (Kermode 1967: 11). Displacement, persecution, or subjugation have left pulsating communal complaints whose slow decay prompted Loizos (1999) to describe them as 'Ottoman half-lives'. On all sides, fantasies of restitution percolate in the imagination, stymied from realization not only by political realities but also by the sheer impossibility of recovering the past. 
Compensation is not the same as restitution; it unsatisfactorily converts prized objects into other terms. But the originals no longer exist, either in themselves or in their contextual moment. They are past and can be restored only in counterfactual

Figure 1 Laurence Sterne, The Life and Opinions of Tristram Shandy, Gentleman, vol. 6,1762 original.

\section{CHAPTER XI.}

I AM now beginning to get fairly into my work; and by the help of a vegetable diet, with a few of the cold seeds, I make no doubt but I shall be able to go on with my uncle Toby's story, and my own, in a tolerably straight line. Now,
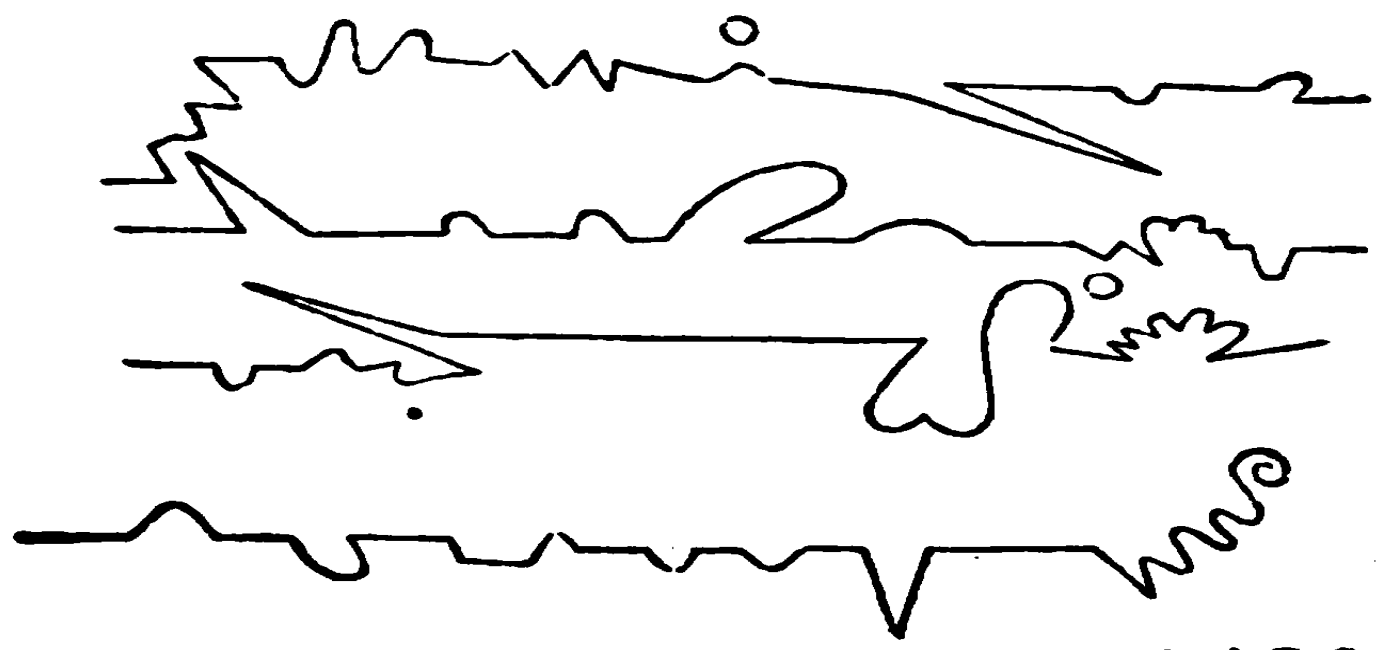

ne. 2. S.

Scal. T. S.

These were the four lines I moved in through my first, second, third, and fourth volumes.-In the fifth volume I have been very good,-the precise line I have described in it being this :-

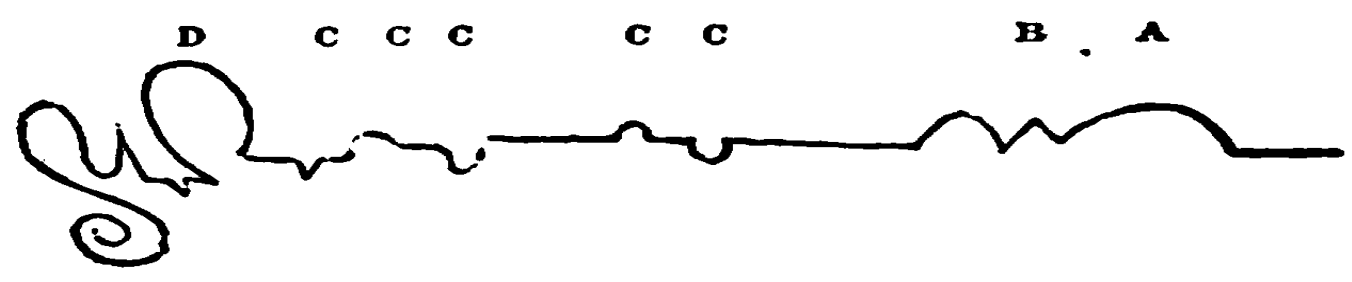

Note: This image can be found in the public domain at https://archive.org/details/lifeand opinions03stergoog. See also Rosenberg and Grafton (2010: 20).132 | Charles Stewart 
imaginings. Even should the original be recovered in a hypothetical act of restitution, the insult and pain of its having been taken in the first instance can never be undone. This restitutive imaginary suffuses the post-Ottoman world, informing a present that, in various modes of consciousness, probes the loss of the past, readily entertains temporal topology, and produces uncanny histories.

\section{Myth and History}

For the most part, topological histories have been studied under the rubric of 'myth' as opposed to history. Topological histories do differ markedly from linear histories, which emphasize objective verification over affective assertion, yet they also share much in common. Interest has accordingly turned to the continuities and commonalities between what were formerly conceived as polar-opposite categories. Mali (2003) examines the catalytic role of myth in the formation of modern historiography, and Samuel and Thompson (1990) consider how historical events can take on moral or gnomic significance, thereby becoming myths that people live by. Anthropological works such as Peter Gow's (2001) An Amazonian Myth and Its History show that myths respond to social change and attempt to comprehend it by creating new analogies between the present and the past, including myths from/about the past (ibid.: 279). If representing and understanding the past is the goal of history, myth becomes very hard to distinguish from history in such cases. Myth is then a form of history.

I adduce a contemporary example from the United States to open up the study of the features of myth and topological history and also as a reminder that 
these are not unusual forms found only in peripheral places such as Amazonia or the post-Ottoman sphere. Jackie Robinson was the first African American major league baseball player. On 15 April 1947, he broke through the color barrier to play for the Brooklyn Dodgers. Like other great players, he was voted into the National Baseball Hall of Fame. But in 1997, 25 years after his death, things took an unprecedented direction when his number was retired for all of baseball. No one on any team can now wear the number 42. Then, starting in 2004, a Jackie Robinson Day (15 April) was instituted during which all players on every team wear the number 42 , and in April 2013, the film 42 was released to coincide with Jackie Robinson Day. Jackie Robinson's life story has become a parable about the struggle for equality and the demise of racism - a story that America likes to tell itself, with more and more fanfare.

Many outstanding baseball players played alongside or against Jackie Robinson, and there are even books and films about some of them. But for the most part they are past personages with no particular afterlife except in the minds of those interested in baseball history. They are the past past. The Jackie Robinson story is certainly history in that it has past factuality, but it operates now more as myth, buttressed by an annual ritual. The difference between history and this particular type of myth, which grows out of historical factuality, is that the emphasis has shifted from a focus on the past per se to a set of images and stories that inform understanding of life today, guiding morality in the present and into the future. Standard history operates as present thought about the past, while myth operates in a timeless present. I say 'timeless' because these sorts of mythical formulations have 
a durability that is not subject to the normal decay of criticism and forgetting. Of course, people know that Jackie Robinson lived in the past, but the truth and meaning of that life now float free from pastness; indeed, it is made present and pointedly so for every player who wears 42 on 15 April. If new historical information should emerge, this will not necessarily affect the myth. The film shows Robinson breaking his bat in the tunnel after being abused by fans. When his wife pointed out that this never happened, the film director responded that it well could have.4 Such poetic license works in line with a coherence theory of truth that resonates with assumptions and feelings about the case at hand, not by a correspondence theory that requires external evidence as a basis for statements. Standard history can grow with new interpretations of existing facts, and it undoubtedly grows when new factual sources, such as a trove of letters or an archaeological discovery, come to light. Myth is always internally growing as the core message continually receives enhancement while remaining impervious to factual criticism.

The everyday semantic difference between myth and history takes myths to be false in contrast to histories. In the view I am taking here, myths and histories can both be true and can overlap, but myths are true at a level different from the scientific methods of evidence and probability that underwrite historiography. History aims for the truth, whereas myth begins as truth. Yet a history can escalate into a myth, and a myth can contract back to history and be largely forgotten. Documentary evidence may not kill myths, but changing times do. Jackie Robinson will be less necessary when racism in America becomes less problematic. "All 
meaning is answerable to a lesser meaning, which gives it its highest meaning," as Lévi-Strauss (1966: 255) put it.

In their account of children during the Greek Civil War (fought between 1946 and 1949), Danforth and Van Boeschoten (2012: 37) expose the power of the term paidomázoma. This word, which literally means the 'gathering up of children', refers to devshirme, the Ottoman practice of selecting Christian children from subjugated peoples throughout the empire and raising them to be loyal Muslim subjects known as Janissaries, who could rise to high public office. During the latter phase of the Greek Civil War, as fighting intensified in northern Greece, both the government army and the resistance forces evacuated children from war zones. The government placed children in care at various institutions in Greece, while the Communist Party evacuated children from its area of control into Eastern Bloc countries, such as Yugoslavia, Romania, and Hungary. Up to the present day, the government and its mainstream supporters refer to the Communist evacuation of children as paidomázoma (rendered as 'abduction' or 'kidnapping' in English), while the government's evacuation is labeled 'child protection' (paidophylagma). This usage of paidomázoma collapsed the Communist evacuation of the late 1940s with an oppressive Ottoman practice, which had ceased by 1700. People were reaching back for an analogy from a distant past-not an episode that anyone knew first-hand, but one that had been passed on in collective memory, very likely through history textbooks, as a quintessentially evil action perpetrated by the archetypal enemy against a helpless Greek nation. This offers another example of history being amplified into a myth that can guide moral action in the present. It resembles the 
even older myth of the tribute of Athenian youths to King Minos of Crete to be fed to the Minotaur.

The historical practice of devshirme contained negative moral potential above and beyond the theme of kidnapping. It also involved conversion to Islam and service to the enemy, themes that came to guide interpretations of latter-day events: the children taken to the Eastern Bloc during the civil war were being converted to communism and/or becoming de-Hellenized and turned into Slavs. To this day, some of these children, now adults, are not allowed to return to settle in Greece as they are not considered ethnic Greeks. It could be argued that the mythicized image of the paidomázoma still animates government policies even though one of the 'deeper meanings' supporting it—-the Cold War-has disappeared.

No matter how much evidence Danforth and Van Boeschoten (2012) produced to document the paidomázoma as a well-intentioned evacuation programand they give details of their public engagement-they could not dislodge the entrenched opinion that the evacuation was a nefarious abduction. The paidomázoma shows how myths may be immune to historicization, while at the same time provoking more and more detailed historiography, such as Danforth and Van Boeschoten's volume.

The life cycle of the mythicized paidomázoma appeared to be winding down after the fall of the military junta in 1974 and the rise of a center-left government, PASOK, which did much to defuse and move beyond the right-left polarization that plagued Greece throughout the twentieth century. This, combined with the end of the Cold War mentioned above, would seem to have eradicated any 'deeper 
meaning' holding the myth in place. Indeed, Greek children born in the 1980s and 1990s grew up unfamiliar with the term paidomázoma. However, with the new polarization in Greek politics brought on by the rise of the extreme right-wing Golden Dawn political party in the twenty-first century, the term has resurfaced and the younger generation are coming to comprehend it. The mythical past may come back, disappear, and then come back again, raising the question of whether powerful historical events such as wars are ever over.

Other mythicizations have difficulty getting off the ground at all. Yannis Hamilakis $(2012,2013)$ wonders how Zeus Xenios (hospitable Zeus/god of hospitality) could have been adopted as the official code name for the Greek government crackdown on illegal immigrants last year. Was this mistaken mythology? In an even more disturbing development, the Golden Dawn party has likened itself to ancient Spartans. At one of their rallies, a speaker compared their mission to the Spartan initiation rite called krypteia (hidden things) in which young Spartans murdered unsuspecting helots (a subjugated serf population) in stealthy attacks. This historical analogy possibly emboldens attacks on innocent migrants such as 26-year-old Shehzad Luqman, a Pakistani who was knifed by motorcyclists. The assailants unscrewed and hid their number plates before speeding away in a modern-day version of krypteia. Mythicization can be ill-conceived or offer a template for criminal violence and still potentially recruit followers.

Historians can never capture the past as it actually was; they can only aspire to that. They must be selective. And they can never eradicate presentism from their accounts, although they do recognize the danger of anachronism and work hard to 
avoid it. History is always history for a certain time and a specific audience. History is organized by temporal sequence; chronology is its deep structure, as Lévi-Strauss (1966: 258ff.) pointed out in The Savage Mind. Myth of the sort under consideration here-that is, the sort bordering on historiography-is structured by affect. The affective resonance of particular events brings them into relationship with other events in an allusive, analogical system.

Daniel Knight (2012), for example, has shown how the biting realities of the current economic crisis in Greece have caused images of the World War II famine and the Greek Civil War to surface in contemporary Greek consciousness. These historical images amplify public apprehension that the sufferings of the past will be repeated in the future. They do so through analogical thinking in which, for example, the German occupation of Athens and the ensuing death by famine of some 300,000 people in the early 1940s are paralleled with the current austerity imposed by the European Central Bank. Current German opposition to a lenient bailout is bitterly felt in Greece, and many political cartoons have cast Germany's chancellor, Angela Merkel, as Hitler. German businesses have taken the lead in loaning Greek farmers the money to buy photovoltaic panels to lay over their fields in order to produce electricity rather than food (see Knight, this issue). Farmers in Thessaly, Greece's breadbasket, complained about the disadvantageous long-term contracts and accompanying loss of control over their land, comparing it to the Ottoman period when they were landless serfs working on large estates known as tsiflíkia (Turk. ciftlik). As one man expressed it: "Greece has become the ciftlik of Europe" (see Knight 2012: 64). 
The foreboding and fear that Ottoman times, Nazi occupation, and civil war incite by their eruption into the present is consistent with Freud's ([1919] 1955: 219,240 ) definition of the uncanny as once familiar matter, encountered by surprise, and with unsettling effect. This historical uncanny is produced by temporal pollution (sensu Mary Douglas)—matter not in its correct temporal place. The year 2013 in Greece was not supposed to be another Ottoman period or a 1942 or a 1948. Greek people have long found these painful pasts hard to contemplate and had consigned them to a twilight of partial memory. The malnutrition endured during famine not only left marks on the bodies of people, but also gave rise to numerous deep psychological reactions to food, such as parents inordinately concerned that their children eat. I always interpreted the refrain pháei, pháei (eat! eat!) as anxious hospitality, but it possibly stems from a basic worry about food itself. Currently, the affective resonances of the Greek present give this past new vitality. It is very different from the Jackie Robinson feel-good story, which has undergone steady amplification. Robinson is a topologically bent story as well as a myth, but it is not uncanny because people want him and have never really forgotten him. By contrast, the stories told to Daniel Knight are feel-bad stories, evil mythology, stories people do not like telling themselves about themselves, but which they cannot stop themselves from contemplating—and telling.

\section{Autonomic History}

Walter Benjamin (1968) offers a perspective on the sudden and surprising aspect of the uncanny apparition of the past. He conceptualizes the past as "an 
image which flashes up" (ibid.: 255) to consciousness in moments of danger, while Taussig (1984: 88) describes it as "history [forming] analogies and structural correspondences with the hopes and tribulations of the present." This imagery of the past comes into mind unexpectedly and "set[s] thinking in motion" (Adorno, cited in ibid.: 89).

Whereas in the contemporary Greek case documented by Knight (2012, this issue) the imagery of the past instigates fear, frugality, melancholy, or even suicide, Benjamin and Taussig see the analogical use of the past as empowering and redemptive. The past comes to hand as a weapon to be used in the fight against injustice, as if there existed "a secret agreement between past generations and the present one" (Benjamin 1968: 254). The spontaneous arrival of the past characterizes a particular moment of social potential, which Benjamin terms the Jetztzeit, the now time, when the oppressed can slip the noose of traditional domination off their necks. The past dead become a source of power in this case, a moral sword in the present, not a premonition of suffering and doom.

The past does not come into mind only when one intentionally decides to think about it. The past is in and around us all the time, cognitively distributed among persons, objects, and landscapes (Birth 2012: 12). Yael Navaro-Yashin (2012) describes this as a situation where people and external objects are also affectively entangled. Affect circulates between them, prompting a post-humanist analysis that does not posit the person as the locus of control (ibid.: 41, 133). Seeing a bullet hole, for example, or passing a grave or massacre site can provoke feelings. This is necessarily a diachronic relationship between the present moment and 
traces made in the past. Navaro-Yashin points out that in the case of Cyprus this past goes back to the 1974 Turkish invasions and partition of the island and therefore lies within living memory.

By contrast, in Kóronos, a settlement in the mountains of the Greek island of Naxos, villagers came into contact with a previously unknown past (Stewart 2012). They dreamed of a buried icon calling out to be unearthed. This was an autonomic, surprising intervention of the past in the life of the community. The history produced in these dreams related to a distant past undocumented by any historical record. The dreams informed people that Egyptian Christians fleeing persecution over a thousand years earlier had deposited the icons. The dreamers vacillated over whether these Egyptians were fleeing Roman persecution in the third century or iconoclasts in the eighth century. Basically, objects representing a compression of past moments of persecution were coming to the surface in order to protect the villagers in a current moment of persecution. In the 1830s, when these dreams first occurred, the Greek state was in the process of nationalizing the local emery mines, thereby impoverishing the people of Kóronos. In these dreams, as again in later dreams during the Great Depression in 1930 (Stewart 2012: 70), saints and material objects spoke to the villagers, and the villagers spoke back to them in their dreams. The historical (Egyptians) and the meta-historical (saints and scenarios of redemption) combined to offer orientation in moments of crisis. The villagers at the time of the Greek War of Independence had not yet been exposed to historicism; they held a Romeic Christian temporal orientation, which assumed the possibility of the past returning to redeem the present. The histories produced were topological 
but, in a Christian context, not necessarily uncanny in the sense of 'weird', since such returns were hoped for. As Freud ([1919] 1955: 244) observed, the uncanny emerges according to rules of genre: "[O]ur own fairy stories are crammed with instantaneous wish-fulfilments which produce no uncanny effect whatever." After the installation of Otto, the Bavarian prince who became king of Greece in 1832, however, Christian dreams caused friction with the emergent historicist suppositions of the state, which duly accused the Naxos dreamers of fraud. The Enlightenment had come later and more abruptly to Greece, and its oppositional attitude of suppression soon began to freight topological histories with ambivalence, thus tilting them toward the uncanny.

\section{Post-Ottoman Topological History}

I earlier referred to Lévi-Strauss's (1966) view that myth is structured by affective resonance and history by chronology, but that was not his ultimate conclusion. He continued on to make the case that history is also constructed by affect and that this comes along with the idea of history as history for something (ibid.: 257). National histories collect a series of emotional moments-wars, violations, victories, and celebrations are assembled on a timeline. The major historical periodizations are most often the epochs that follow wars or other disasters: the Pax Romana, the post-World War II period, or post-Katrina New Orleans. Societies orientate themselves in relation to disruptive events and then reorientate after new cataclysmic events. The philosopher of history Frank Ankersmit (2002) contends that this is because traumatic events throw people into a direct relationship with 
reality, which reveals its radical strangeness. Trauma is thus the beginning of historical consciousness because it "is the sublime and vice versa and at the bottom of both is an experience of reality that shatters to pieces all our certainties, beliefs, categories and expectations" (ibid.: 75-76). I take Ankersmit's use of 'trauma' in the sense of emotionally overwhelming, rather than in the psychiatric PTSD sense. Historical consciousness establishes links, whether analogical or chronological, between these accumulating sublime experiences.

Reactions to the burning of the Madımak Hotel in Sivas, a central Anatolian town, illustrate this last point. A mob set fire to the hotel in 1993, killing 37 visitors who had been invited to attend a cultural festival. An Alevi association-Alevism being a minority branch of Islam in predominantly Sunni Turkey—had organized the festival. Most of those who perished were Alevis, and they are mourned by the Alevi community and viewed as martyrs. Their martyrdom has been commemorated over the years by public demonstrations in Sivas on the anniversary of the events, accompanied by demands for government accountability. These demonstrations have become very large gatherings of Alevis and their supporters from all over Turkey and Europe. The state approaches their day of commemoration with heavy security precautions in the form of barricades that prevent the crowd from coming close to the Madımak Hotel site, which supporters want to see converted into a memorial to the martyrs. Every year, then, police containment strategies cause those attending the demonstration to re-experience sensorially the authority of the state in conditions approaching those of the original incident-a form of political historical re-enactment. 
There is a history of contestation and mutual suspicion between Alevis and state authorities in Turkey, and this context disposes the Alevi community to conceive of the "Sivas Massacre" as "one in a long chain of atrocities" (Çaylı 2014: 20), exhibiting an "ethnohistorical ideological conflation" (Mandel 2008: 255). This iterative relationship to martyrdom is evoked and inculcated in the central Alevi ritual known as cem, which involves emotive identification with the Twelve Imams, or martyrs, represented by candles that are extinguished at the climax of the ceremony (ibid.: 280; see also Tambar 2011). Past, present, and future atrocities are activated (or anticipated) and rolled into one timeless post-Ottoman topological experience during the cem.

The Sivas Massacre has been fitted into this structure of historical consciousness and placed in strong relation to one particular preceding martyrdom: the execution of Pir Sultan Abdal, a sixteenth-century minstrel who was accused of fomenting revolt against Ottoman authority. As Çaylı (2014: 20) explains:

[Pir Sultan Abdal] is believed to have later been hanged in Sivas by the governor. The 1993 culture festival in Sivas, whose guests were targeted by the arsonist mob, was named after Pir Sultan, while also a state sponsored sculpture reputedly depicting him was erected in a public square in Sivas the night before the festival. On July 2nd, prior to setting the hotel on fire, the arsonist mob defaced this monument and demanded its toppling ... [In an attempt to reduce tension] the local municipal and state authorities decided to meet the mob's request and brought them the toppled monument as proof. This is believed to have further encouraged the perpetrators. 
The Sivas martyrs and the martyrdom of the sixteenth-century Pir Sultan are thus intimately linked, and the Pir forms part of a larger martyrology extending back to the martyrdom of Husayn at Karbala in ad 680. It is as if the martyrdom of Husayn in the past were like a huge star, with other events of lesser magnitude within its gravitational field. The Sivas Massacre will perhaps grow in size inside collective historical consciousness as time goes by and exert its own pull on future events. Experientially, all of these events can be felt as compacted into one present swirl: a "time-knot," to use Chakrabarty's (2000: 112) Bengali expression, a vortex, or even a black hole, to remain consistent with the galactic imagery. Each phase is co-present, embedded into the others, giving a multi-temporal emotional resonance to the present moment.

\section{Uncanny History}

As Karl Mannheim ([1924] 1952: 85-86) put it: "Historicism ... is a Weltanschauung [that] not only dominate[s] our inner reactions and our external responses, but also determine[s] our forms of thought. Thus, at the present stage, science and scientific methodology, logic, epistemology, and ontology are all moulded by the historicist approach." The central idea of historicism is that time is divided into past, present, and future. The past is over with and knowable, and the future is yet to come and unknowable, although predictable to a certain degree. As time goes by, society builds on its past, and this past becomes recognizably past. The uncanny arises as a scandal to this certitude. Freud's essay on the uncanny, written around the same time as Mannheim's diagnosis of pervasive historicism, rests on 
the bedrock of this historicism. The uncanny surprises and shocks because it violates the intuitive temporal ontology of modernity. The uncanny arises as a stark identifiable figure against the background of historicism.

Mannheim was not, however, entirely accurate. Historicism had become hierarchically dominant in his time, but other forms of relating to the past continued to exist in its shadow. Spiritism, for example, flourished in the 1920 s as a bereaved population attempted to communicate with those killed during World War I. In any case, human beings constantly produce other relationships to time. Temporal linearity may be an objective system of measurement, but it does not necessarily capture the quality of lived temporality. Phenomenologists beginning with Husserl have shown that temporal experience can be fused in a past-present-future where knowledge from the past collides with projections of the future in present perception and action (Gell 1992: 221). Heidegger expanded this in his particular existential ontology where Being is orientated to the future, the past, and then the present, often in that order, although in principle human beings experience temporality in any order. At different times people live profoundly toward the future, whether hopefully or anxiously, and at other times are burdened by the past or not able to supersede it.

The view suggested by phenomenology is that experiencing the past or the future in the present is a perennial human trait, not an optional or easily suppressible feature. Linearity has not obliterated other temporalities, but rather coexists with them unstably in the multi-modal ontology referred to earlier. Paul Ricoeur (2004: 393) takes up this point when reflecting on the challenge that school 
history poses for collective memory.5 Personal, familial, and communal histories transmitted by known people in relation to familiar places and objects make sense. These local histories may, as exemplified by the cases considered above, resort to topological time structures and affective connections in order to impart their messages. School history textbooks come as 'externalities'—not only written but also couched in hard-to-assimilate terms of chronology and names. Scholastic historiography can present the community with novel facts, but my point is that it challenges them with an odd way of knowing.6

For Ricoeur (2004: 394), learning from schoolbooks involves gradual familiarization with "the uncanniness of the historical past." At first, historicism is itself uncanny in the sense of disturbing or disquieting, even shocking, when introduced into non-historicist settings. In time, however, people bring historicist structures into relation with local, perhaps more topological and affectively driven forms of historicizing, such as the dream apparitions of saints on Naxos or the emotive historical consciousness of martyrdom among Alevis in Turkey. Ultimately, uncanny histories are not just the product of a historicist measuring stick. It is the tension and instability between local non-historicism and historicism (often purveyed by the state or other authorities) that continually produce experiences of uncanny histories (Bryant 2014: 682). Uncanny histories expose the incomplete synthesis between two different genres of history. At the same time, unresolved grievances or disputes over facts keep uncanny histories vital as the necessary mode of grounding alternative pasts in the certitude of experience. 


\section{Acknowledgments}

I wish to thank Eray Çaylı and Ruth Mandel for commenting on an earlier draft of this article.

\section{Notes}

1. As a branch of geometry, topology allows consideration of shapes that have been bent and not merely stretched, as in standard geometry. A plate and a bowl made out of wet clay can be shaped back and forth into one another without the need to break any lines, and they are therefore topological variations of one another.

2. As Sterne (1760: 163) put it: "Digressions, incontestably, are the sunshine;-they are the life, the soul of reading;--take them out of this book, for instance,-you might as well take the book along with them;-one cold eternal winter would reign in every page of it."

3. Freud ([1919] 1955: 223; italics in original) quoted Schelling to make this central point in his essay: "Unheimlich is the name for everything that ought to have remained ... secret and hidden but has come to light."

4. One of the actors in the film commented: "At some point he had to break, and the fact that Rachel Robinson didn't fight us to take [the scene] out [of the film], to me proves that it is true." See: http://www.historyvshollywood.com/reelfaces/42-movie-jackie-robinson.php (accessed 5 January 2014). 
5. Bryant's (2014) study of property in occupied territory after the partition of Cyprus applies Ricoeur's ideas and comes to conclusions about the 'unhomeliness' of history that inform my discussion.

6. This parallels the reaction to the imposition of dogmatic theology on local religion. In reaction to reformist imams pronouncing on proper practice, a local Bosniak Muslim objected to "the dead tradition contained in books" (Henig 2012: 761).

\section{References}

Ankersmit, Frank R. 2002. “Trauma and Suffering: A Forgotten Source of Western Historical Consciousness.” In Rüsen 2002, 72-84.

Benjamin, Walter. 1968. "Theses on the Philosophy of History." In Illuminations. Ed. Hannah Arendt; trans. Harry Zohn, 253-264. New York: Schocken.

Birth, Kevin K. 2012. Objects of Time: How Things Shape Temporality. New York: Palgrave Macmillan.

Bloch, Maurice. 1977. "The Past and the Present in the Present." Man 12 (2): 278291.

Bryant, Rebecca. 2014. “History's Remainders: On Time and Objects after Conflict in Cyprus." American Ethnologist 41 (4): 681-697.

Burke, Peter. 2001. "Western Historical Thinking in a Global Perspective-10

Theses." In Rüsen 2002, 15-30.

Çaylı, Eray. 2014. “Architectural Memorialization at Turkey's 'Witness Sites': The 
Case of the Madimak Hotel." In Contemporary Turkey at a Glance: Interdisciplinary Perspectives on Local and Translocal Dynamics, ed. Kristina Kamp, Ayhan Kaya, E. Faut Keyman, and Özge Onursal Bes,gül, 13-24. Berlin: Springer.

Chakrabarty, Dipesh. 2000. Provincializing Europe: Postcolonial Thought and Historical Difference. Princeton, NJ: Princeton University Press.

Danforth, Loring, and Riki Van Boeschoten. 2012. Children of the Greek Civil War: Refugees and the Politics of Memory. Chicago: University of Chicago Press.

Eliade, Mircea. 1971. The Myth of the Eternal Return: Or, Cosmos and History. Trans.

Willard R. Trask. Princeton, NJ: Princeton University Press.

Freud, Sigmund. [1919] 1955. “The Uncanny." In The Standard Edition of the Complete Psychological Works of Sigmund Freud, Volume XVII (1917-1919): An Infantile Neurosis and Other Works. Trans. James Strachey, 217-256. London: Hogarth.

García Marín, Álvaro. 2015. “The Origin Is Already Haunted: Greece as the Uncanny of Modernity." Modern Greek Studies Online 1: A1-A22.

http://www.moderngreek.org.uk/journal/content/garcia2015.

Gell, Alfred. 1992. The Anthropology of Time: Cultural Constructions of Temporal Maps and Images. Oxford: Berg.

Gow, Peter. 2001. An Amazonian Myth and Its History. Oxford: Oxford University Press. 
Hamilakis, Yannis. 2012. “Hospitable Zeus.” LRB blog, 8 August. http://www.lrb.co.uk/blog/2012/08/08/yannis-hamilakis/hospitable-zeus (accessed 20 June 2015).

Hamilakis, Yannis. 2013. “Spartan Myths.” LRB blog, 14 February. https://www.lrb.co.uk/blog/?s=Spartan+Myths (accessed 20 June 2015).

Harris, Oliver J. T., and John Robb. 2012. "Multiple Ontologies and the Problem of the Body in History." American Anthropologist 114 (4): 668-679.

Henig, David. 2012. “'This Is Our Little Hajj': Muslim Holy Sites and Reappropriation of the Sacred Landscape in Contemporary Bosnia." American Ethnologist 39 (4): $751-765$.

Kermode, Frank. 1967. The Sense of an Ending: Studies in the Theory of Fiction. Oxford: Oxford University Press.

Knight, Daniel M. 2012. "Turn of the Screw: Narratives of History and Economy in the Greek Crisis." Journal of Mediterranean Studies 21 (1): 53-76.

Latour, Bruno. 1993. We Have Never Been Modern. Trans. Catherine Porter. Cambridge, MA: Harvard University Press.

Leach, Edmund. 1961. "Two Essays Concerning the Symbolic Representation of Time." In Rethinking Anthropology, 124-136. London: Athlone.

Lévi-Strauss, Claude. 1966. The Savage Mind. Chicago: University of Chicago Press. Loizos, Peter. 1999. “Ottoman Half-Lives: Long-Term Perspectives on Particular Forced Migrations." Journal of Refugee Studies 12 (3): 237-263.

Mali, Joseph. 2003. Mythistory: The Making of a Modern Historiography. Chicago: University of Chicago Press. 
Mandel, Ruth. 2008. Cosmopolitan Anxieties: Turkish Challenges to Citizenship and Belonging in Germany. Durham, NC: Duke University Press.

Mannheim, Karl. [1924] 1952. "Historicism." Essays on the Sociology of Knowledge: Collected Works Volume 5. Ed. Paul Kecskemeti, 84-133. London: Routledge.

Navaro-Yashin, Yael. 2012. The Make-Believe Space: Affective Geography in a Postwar Polity. Durham, NC: Duke University Press.

Ricoeur, Paul. 2004. Memory, History, Forgetting. Trans. Kathleen Blamey and David Pellauer. Chicago: University of Chicago Press.

Robbins, Joel. 2007. “Continuity Thinking and the Problem of Christian Culture: Belief, Time, and the Anthropology of Christianity." Current Anthropology 48 (1): 5-38.

Rosenberg, Daniel, and Anthony Grafton. 2010. Cartographies of Time: A History of the Timeline. New York: Princeton Architectural Press.

Royle, Nicholas. 2003. The Uncanny. Manchester: Manchester University Press. Rüsen, Jörn, ed. 2002. Western Historical Thinking: An Intercultural Debate. New York: Berghahn Books.

Samuel, Raphael, and Paul R. Thompson, eds. 1990. The Myths We Live By. London: Routledge.

Sterne, Laurence. 1760. The Life and Opinions of Tristram Shandy, Gentleman. Vol. 2. London: Dodsley. https://archive.org/details/lifeandopinions03stergoog (accessed 20 June 2015).

Stewart, Charles. 2012. Dreaming and Historical Consciousness in Island Greece. Cambridge, MA: Harvard University Press. 
Tambar, Kabir. 2011. “Iterations of Lament: Anachronism and Affect in a Shi'i Islamic Revival in Turkey." American Ethnologist 38 (3): 484-500.

Taussig, Michael. 1984. “History as Sorcery.” Representations 7: 87-109.

Zerubavel, Eviatar. 2003. Time Maps: Collective Memory and the Social Shape of the Past. Chicago: University of Chicago Press. 